The Relationship Between Economic Growth and Environmental Pollution: Testing The Environmental Kuznets Curve Hypothesis in Egypt

* Ramadan El. A. Maen ,Associate Professor of Economics, Faculty of Commerce, Tanta University, Egypt. E-mail:Ramadan_elsayed@Commerce.tanat.edu.eg.

Maie M. Kamel, Associate Professor of Statistics, Faculty of Commerce ,Tanta University, Egypt.E-mail: maie.kamel@commerce.tanta.edu.eg 


\title{
The Relationship Between Economic Growth and Environmental Pollution: Testing The Environmental Kuznets Curve Hypothesis in Egypt
}

\author{
Ramadan El. A. Maen
}

Maie M. Kamel

\begin{abstract}
:
The aim of This study is to verify the existence of the EKC hypothesis and to analyze and measure the nature of the relationship between $\mathrm{CO} 2$ emissions, energy consumption, economic growth, trade openness and Foreign Direct Investment in Egypt over the period of 1977-2014, using cointegration and Granger causality approach. The result suggests that there exists a long-run relationship among the variables and the Environmental Kuznets Curve (EKC) hypothesis is supported.
\end{abstract}

Keywords: Environmental Kuznets Curve (EKC), Environmental Pollution, $\mathrm{CO} 2$ emissions, Energy consumption, Foreign trade, Foreign Direct Investment , Cointegration Analysis.

\section{1- Introduction:}

The interest in environmental pollution emerged after the Industrial Revolution, until the economics of the environment became one of the branches of economics. In the 1990s, increasing attention was paid to the relationship between economic growth and environmental pollution. This relationship became one of the most important hypotheses in the environmental economy. Researchers. In this field description of the relationship between environmental pollution and economic growth in the Environmental Kuznets Curve (EKC) Hypothesis, will be assumed.

This hypothesis was first proposed by Grossman and Krueger (1991), advocating for the EKC hypothesis to be formally adopted by the World Bank in its World Development Report in 1992. The EKC model is used to measure the relationship between economic growth and environmental quality.

According to the hypothesis, this relationship takes the form of an inverseU-shaped pattern Frankle \& Rose (2003). In the early stages of manufacturing,there is a positive correlation between average per capita GDP and environmental pollution, in which the level of emissions and the concentration of pollution increases with the growth of manufacturing processes. Ignoring the importance of the environment using non-clean technologies. This relationship becomes irreversible in the advanced stages of growth, rising incomes and increasing environmental awareness, thus increasing the demand for goods that are less corrosive to the environment. Thus, after the turning point, qualitative indicators improve, with reduced pollution and environmental degradation Taguchi (2012). Through extensive experimental studies on different countries and using different methods of measurement, indeed, this hypothesis was confirmed by a few researchers. However, it was also refuted by a few other researchers. There are some studies noticed that the 
relationship is in the form of $\mathrm{U}$ and others noted that the relationship between the two variables takes the form of an inverse $\mathrm{U}$.

Despite the positive effects of economic growth on the improvement of per capita income and the standard of living, the pattern of production is a threat to environmental resources through the emergence of environmental problems such as pollution and access. Therefore, the concept of sustainable development should consider the environmental constraints and general development policies by balancing environmental considerations and development priorities, and economic growth would be for the benefit of the environment and not at its expense.

The importance of this study stems from the nature of the interrelationships between the economic variables and the environmental variables, as they represent the main pillars on which the economic activity of society is based. The economy cannot play its fundamental role in meeting the needs of society without maintaining a balance between economic activities and the conservation of environmental resources in the sense of economic growth without prejudice to the components of the ecosystem and the depletion of resources, and to highlight the economic factors that affect the environmental pollution represented by the emissions of $\mathrm{CO}_{2}$.

The paper is an effort to fill the gap in the energy literature, and investigate the relationship between $\mathrm{CO} 2$ emissions and economic growth in Egypt. The plan of this paper will be as follows : section2 provides a survey 0 Literature highlighting relevant previous studies on the subject. Section 3 shows Economic Growth and The Environment, section4 details Model and Methodology, section5 Empirical Study, section 6 Conclusion and Policy Implications

\section{2 - Literature Review:}

There have been numerous studies on the relationship between economic growth and environmental pollution under the hypothesis of the EKC which were aimed at ascertaining whether there is an inverse relationship between economic growth and environmental pollution, both at the level of developed and developing economies.

These studies differ in terms of the variables used, the method of statistical analysis used and the period of study. The literature shows two strands of linkage between energy consumption and $\mathrm{CO} 2$ emissions, i.e. economic growth and $\mathrm{CO} 2$ emissions, economic growth and energy consumption.

First, the studies confirmed the existence of the EKC hypothesis include the Asante (2016) study, which examined the relationship between economic growth and $\mathrm{CO} 2$ emissions, energy consumption and trade openness in Ghana during the period 1980-2011. The results of the measurement using the Hendy Error Correction Model and Granger Causality Long-term study variables and carbon dioxide emissions, supported the EKC hypothesis in the long-term. The study of Sunday (2016) on the application of the EKC hypothesis to subSaharan Africa using the model of common integration and the root of unity during the period 1980-2012. 
The study of Monserrate et al. (2016) used the ARDL model on Iceland during the period 1960-2010 confirmed a long-term relationship between economic growth and environmental degradation. Ben jebli et al. (2016) examined the validity of this hypothesis in the OECD countries during the period 1980-2010. The validity of the EKC hypothesis in the countries under study showed that trade and renewable energy consumption would contribute to reducing $\mathrm{CO} 2$ emissions. In examining the validity of the EKC hypothesis in Croatia, the results of Josic et al. (2016), during the period 1990-2013, showed that economic growth affects carbon dioxide emissions in the short-term and there is no relationship between them in the long-term. The study of Ahmed et al. (2012), through the application of the ARDL methodology to Pakistan during the period 1971-2008, showed an inverse correlation between economic growth and carbon dioxide emissions. The results showed that trade improves environmental quality, while population density and energy consumption increase environmental degradation.

In another recent study on Croatia prepared by Ahmed et al. (2016) during the period 1992-2011 using the ARDL methodology, the results confirmed the validity of the EKC hypothesis in the long-term. In the same methodology, Saboori et al. (2012) studied Malaysia during 1980-2009 and Shahbaz et al. (2014) studied Tunisia during the period 1971-2010. The hypothesis is reversed in both the short- and long-term. The Apergis and Payne (2010) study of 11 Commonwealth countries during the period 1992-2004 found that the estimated results supported the hypothesis of the Kuznets environmental curve in the form of a reversed U-shape.

The Srinivasan study came (2014) to examine the causal relationship between energy consumption, $\mathrm{CO} 2$ emissions, economic growth, and trade exchange in India using the VECM vector. Farhani and Ozturk (2015) examined the causal relationship between carbon dioxide emissions, GDP, energy consumption, financial development, trade openness, and urbanization in Tunisia during the period. The results of the study showed a significant positive correlation between energy consumption, $\mathrm{CO} 2$ emissions, economic growth and trade. In 1971-2012 using the ARDL model, the results of the study showed a positive relationship between local credit of the private sector as an indicator of financial development and environmental pollution; a long-term relationship between GDP and carbon dioxide emissions; and a positive relationship between trade openness and $\mathrm{CO} 2$ emissions. The study also found a positive relationship between urban expansion and energy consumption.

Song et al. (2008) examined the relationship between economic growth and environmental pollution in China, using panel data during the period 1985-2005 . On the basis of the Kuznets environmental curve hypothesis and the use of Cointegration. The results showed a relationship in the form of an inverse-U-shaped pattern. While Krueger and Grossman (1995) analyzed the Kuznets environmental curve to study the environmental effects of the Free North America Agreement, through panel data for 42 countries. The results showed a long-term relationship between economic growth and carbon dioxide emissions 
in the form of an inverse-U-shaped pattern. Harbaugh et al. (2001) attempted to verify the existence of the Kuznets environmental curve, using cross-sectional data for a sample of countries during the period 1971-1992. The results showed that economic growth affects the ecosystem and supports the Kuznets environmental curve.

Second, there are studies that did not confirm the existence of the EKC hypothesis: such as the study of Och M. (2017), which examined the relationship between nitrous oxide emissions, economic growth, exports and urbanization. The results of the Granger causality assessment showed a long-term U-shaped relationship, which is not supported by the EKC hypothesis. Ozokcu et al. (2017) showed that the relationship between economic growth and environmental pollution is in the form of an $\mathrm{N}$ in the OECD countries and in the opposite form for developing countries. The study selected 26 countries from the OECD and 52 developing countries during 1980-2010. Sulaiman et al (2012) study showed the dynamic relationship between $\mathrm{CO} 2$ emissions, economic growth, energy consumption and trade openness, based on the EKC hypothesis in Indonesia during the period 1971-2007, using the Autoregressive Distributed Lag (ARDL). The estimation results do not support the EKC hypothesis. It is inverse relationship between economic growth and environmental degradation, and trade openness is the most widely interpreted variable of long-term $\mathrm{CO} 2$ emissions. Using the same method, the Gebli et al. (2015) study found the same result applied to Tunisia during the period 1980-2009. Non-renewable energy consumption and trade exchange positively affect carbon dioxide emissions; while renewable energy consumption negatively impacts $\mathrm{CO} 2$. The least squares method The results of Tevie.J et al. (2011) study in the United States of America in 2007 showed 48 states using Modex index to assess the risks of biodiversity, the estimation results do not support the EKC hypothesis.

\section{A Review of Previous Studies Can Draw The Following Conclusions:}

1. Some studies have shown that there is a common integration of variables, which is consistent with the results of the EKC hypothesis in the existence of long-term joint integration relationships between variables.

2. Some studies have shown a two-way causal relationship between energy consumption and GDP, and CO2 and GDP.

3. Some studies have shown that there is no causal relationship between the variables, which does not support the existence of the EKC hypothesis.

4. The importance of the present study is due to the absence of enough studies to examine the economic factors affecting the environmental degradation applied to the Egyptian economy and that this relationship needs further research and study.

\section{3-Economic Growth and The Environment: Conceptual Framework}

The concept of Externalities is the basis for integrating the environmental dimension into economic models. This is due to the absence of a market for environmental goods, in which prices are determined in addition to the rule of free ,such as those governing the dynamics of physical capital (the difference between 
investment and Depreciation), considering the change or growth in the quality of the environment is the result of the difference between nature's ability to renew and the level of pollution. The higher the capacity for regeneration and reprocessing of polluting emissions, the quality of the environment has improved over time.

The following is a presentation of some models that introduced the environmental dimension:

\section{3-1-Walt Rostow's Stages of Economic Growth Model}

This theory attempted to address environmental problems resulting from poverty as a socioeconomic phenomenon during the cumulative stages representing the episodes that lead to each other, thus addressing the problems facing the environment in the framework of addressing the poverty and environmental pollution problems faced by both rich and poor countries. The existence of the main episodes of poverty and underdevelopment related to the scarcity of capital and the consequent low-income level, and then the reduction of savings and investment and productivity, and return to lower income level, which requires a break in this circle in one of the episodes. Based on this theory, poverty is a cause of environmental problems, considering that poverty is an environment of a cumulative nature. Rostow w.(1959)

\section{3-2 - Theory of the pattern of international economic relations and the division of international labor:}

According to this theory, developing countries specialize in supplying raw materials and food products to industrialized countries. At the same time, developing countries are a market for the disposal of industrial products. This theory provides an explanation for the structural changes in developing economies and associated environmental problems that vary from state to state through the direction of individual behaviors with negative impact on the environment. According to the modern theory of international trade, the effect of size and technical level of production leads to a decrease in pollution, and the liberalization of international trade has a positive effect on the environment. In the view of the liberalization of trade, when it increases per capita GDP by $1 \%$, income changes associated with international trade and technological progress lead to reduced pollution. Changes resulting from capital accumulation and impact on income lead to a high level of pollution, as capital accumulation increases the production of pollution-intensive goods, while this does not occur in the case of technological progress and international trade. The impact of economic growth on pollution depends on the source of this growth (1993). Gene Grossman and Alan Krueger

Anteiler et al. (2001) attempted to develop a theoretical model to measure the effects of trade on environmental pollution, which was divided into three effects: Scale Effects, Technical Effects .

Scale Effects refer to the environmental effects of increasing production volume. As trade openness increases, it has a negative impact on the environment, increasing emissions, along with increasing economic activity. 
Technical Effects are the shift to cleaner production methods in response to the demand for environmental goods, which is caused by the increase in income resulting from trade liberalization.

The effect of increased trade is positive for the environment, where emissions decrease with the increase in the cleaner production .Tobey J. (1990).

The effects of the production composition show that changes in the quality of production resulting from trade affect the environment. The assumption of the Pollution Havens hypothesis suggests that relatively lowincome poor countries will be more polluted with trade openness because they adopt less stringent environmental policies.

The costs of reducing thalidomide, giving it a comparative advantage in the production and export of polluting goods .Qureshi (2005)

\section{3-3- Rebelo AK Growth Model}

The model of Sergio T. Rebelo (known as the AK model) is based on the test of the effects of environmental policies on economic growth in many studies. This research, despite its variation in variability, led to a contradiction between the environment and economic growth. The improvement in the quality of the environment is accompanied by a decline in growth rates and vice versa. To overcome this, pollution control activities have been integrated into an environmental sector or technology. These studies have shown that although the harmful effects of pollution are reduced by these activities, they create a competitive effect on consumption and investment, thus reducing the economic growth rate. This effect can be minimized by considering the productivity effect; improved productivity and thus increased economic growth rate. Rebelo, Sergio T. (1991).

\section{3-4 - Lucas model}

The Robert E. Lucas (1988) studied human capital and its role in economic growth as the basis for theories of internal growth on the one hand, and the study of the effects of pollution on growth. Two methods have been distinguished in modeling the effects of pollution in human capital: On the negative impact of pollution in training activities, whether as a factor of human capital depletion, which reduces the time allocated for training, or as affecting the effectiveness of the educational system. The second method is explicit. It goes to the effect of pollution in the life span, without affecting the accumulation function. This method, considering the effects of productivity, is reduced by illness, absenteeism, or total absence due to death.

\section{3-5- A Model Of Growth Through Creative Destruction}

Given the impact of technological innovation on economic growth and environmental pollution, the framework has been adopted to analyze various economic and environmental policies and to identify the conditions under which development priorities and environmental considerations converge and require state intervention to correct market failures resulting from the difference between the private cost and the social cost of pollution, especially as the environment 
suffers from the problem of property rights, the excessive exploitation of resources, and the impact of the processes that lead to the deviation of optimal levels of growth from their competitive levels . Aghion P. and Hewitt P (1992).

In this context, an environmental tax could be applied that would prompt institutions to use pollution control activities and engage in research and development to create clean and environmentally-friendly technology. Such an environmental policy would promote environmental awareness and strengthen economic instruments with standards and legislation that would enable the integration of the environmental dimension into the economic account of producers and consumers alike. Scotchmer S. and. Menell .P. (2005)

\section{3-6 - Porter's Model of Generic Strategies for Competitive Advantage}

Porter is one of the most important pioneers in reconciling the environment and the economy by highlighting the role of environmental innovations in raising the competitiveness of companies. Porter based his analysis on the hypothesis that strict environmental regulations can reduce production and increase the competitiveness of companies by stimulating environmental innovation, which leads to improved economic performance. Porter M.(2008)

\section{3-7 - Environmental Kuznets Curve (EKC)}

The inverted-U relationship between pollution and growth derives its name from the work of Kuznets (1955) who postulated a similar relationship between income inequality and economic development .Dinda,(2004)..There is a mutual effect between economic growth and the environment. While economic growth is affected by the scarcity and availability of natural resources, rapid economic growth affects the abundance and quality of available environmental resources and may therefore lead to environmental degradation. Grossman and Krueger (1991) show the inverse relationship between economic growth and environmental pollution. The relationship between the two variables takes the opposite of U.(see Figure 1.)

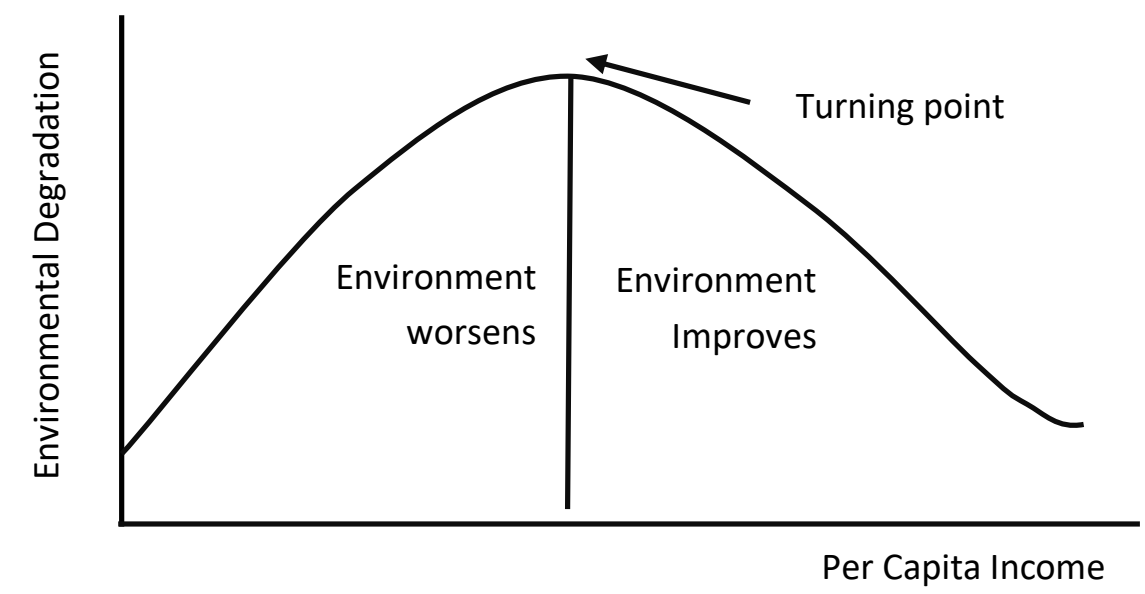

Figure 1. Environmental Kuznets Curve (EKC)

Kuznets believes that there is a direct correlation between average per capita income and environmental pollution. This negative relationship turns into an inverse relationship in the advanced stages of growth and an increase in the 
demand for less environmentally polluting goods, leading investors to increase production of environmentally clean goods. The Kuznets model has been developed by many econometrists using regression models by suggesting that water and air pollution increases with development until per capita income is between $\$ 5,000$ and $\$ 8,000$. When income rises above that level, pollution starts, as appears in the traditional form of the Kuznets curve (EKC).

\section{Economic Impacts of Environmental Pollution:}

Environmental pollution refers to all factors affecting the living environment of plants, animals and humans, or affects the formation of nonliving natural elements such as air, sea, rivers, soil, etc., leading to the degradation of the components of the environment. Environmental pollution is called cross-border pollution when the source of pollution is one of the states and produces damage that is transferred to another country via air or water. Carbon dioxide is one of the most important sources of air pollution and is the result of the complete combustion of various types of fuel such as coal, petroleum, natural gas and with the increase of carbon fuel combustion. Since the industrial revolution, the concentration of $\mathrm{CO} 2$ has increased, leading to global warming.

In addition to the presence of global warming, the phenomenon of acid rain, which includes dangerous chemicals, erodes plowing and planting, as well as the fragility of the ozone layer, which prevents harmful types of solar radiation from depletion to the ground; and water pollution leads to the emergence of many diseases and soil pollution to the degradation of fertile arable land.

\section{4- Model and Methodology}

The Kuznets curve model can be expressed to measure the relationship between economic growth and environmental pollution in the following formula

$$
C \mathrm{O}_{2}=f(G D P, E c, D O T, F D I)
$$

Where is: $\mathrm{CO}_{2}$ is $\mathrm{CO}_{2}$ emissions per capita,

GDP is real GDP per capita ( constant 2010).

EC is energy Consumption per capita.

DOT is the degree of trade openness .

FDI is Foreign Direct Investment per capita.

The linear model

$$
\ln C O_{2 t}=\alpha_{0}+\beta_{1} \ln G D P+\beta_{2} \ln E C+\beta_{3} \ln D O T+\beta_{4} \ln F D I+\mu_{t}
$$

Where $\mu_{t}$ is the error term

$$
\mu_{t} \sim N\left(0, \sigma_{e}^{2}\right)
$$

\section{Study variables:}

1- CO2 emissions:

$\mathrm{CO} 2$ emissions are defined by an information analysis center in the United States, such as emissions from burning fossil fuels and the cement industry. The result of fuel consumption is either solid, liquid, or gaseous. 


\section{2- Real GDP:}

The gross domestic product (GDP) is an important economic indicator for any country. It reflects the total activity of the state and its economic performance over a period, which is reflected in the economic situation in the country: the level of employment and the standard of living, exports and imports, capital accumulation and the general budget of the state.

\section{3- Energy consumption (EC):}

Energy resources are one of the most important inputs to the production process and are the main engine of economic growth.

\section{4- Foreign Direct Investment(FDI):}

Different pollution reduction policies between countries lead to the transfer of foreign direct investment to countries with lax environmental policies.

\section{5- Degree of trade openness(DOT):}

The degree of trade openness is measured by dividing the total value of exports and the value of imports by the national income, multiplied by 100 .

\section{Steps for estimating the model:}

First, check the stability of the time series of the variables studied.

Analyze the time series to ensure stability before testing the causal relationship through the unit root tests and determine the degree of integration of the time series.

Second, test the root of the unit tests and determine the rank of integration.

The root of the unit is used to determine the degree of integration of the time series of the variables to determine whether the variables are stable. The study will be based on the Adi-test and the null hypothesis test for non-stability of the time series (i.e. the root of the unit).

\section{Third, Granger's Causality Test}

Studying the stability of the time series of the variables and determining the causal relationship between the emissions of carbon dioxide and the independent variables was based on the test of the causality of Granger.

The nude takes the following picture:

The null hypothesis indicates that there is no causal relationship in the case of the computation less than the scale and is accepted in addition to the probability that value $\mathrm{p}$ is greater than $5 \%$.

\section{Iv- Johanneson Integration Course}

To prove the existence of a long-term relationship between the variables of the study, the study was based on the test of joint integration of Johansen and the possibility that this test will identify several vectors of the integration of the variables in a manner of maximum potential, depending on two tests:

Trace test and the eigenvalue max

These tests are based on the Likelihood Ratio Test. The impact test estimates the maximum number of integration vectors ( $r$ ) versus the alternative hypothesis, if the number of integration vectors is (n). While the intrinsic value is correlated with the 
impact test in the nondestructive hypothesis, they differ in the alternative. The alternative option for testing intrinsic value is that the number of integration vectors is $\mathrm{r}+1$.

\section{5- Empirical Study}

the annual data from 1977 to 2014 for the study were obtained from the word development indicators database

(https://databank.albankaldawli.org/data/indicators), Using SPSS 25 and E-views 7 Software.

- To test the nature and the relationship between variables . Table (1) represent the correlation between variables and the significant for each one.

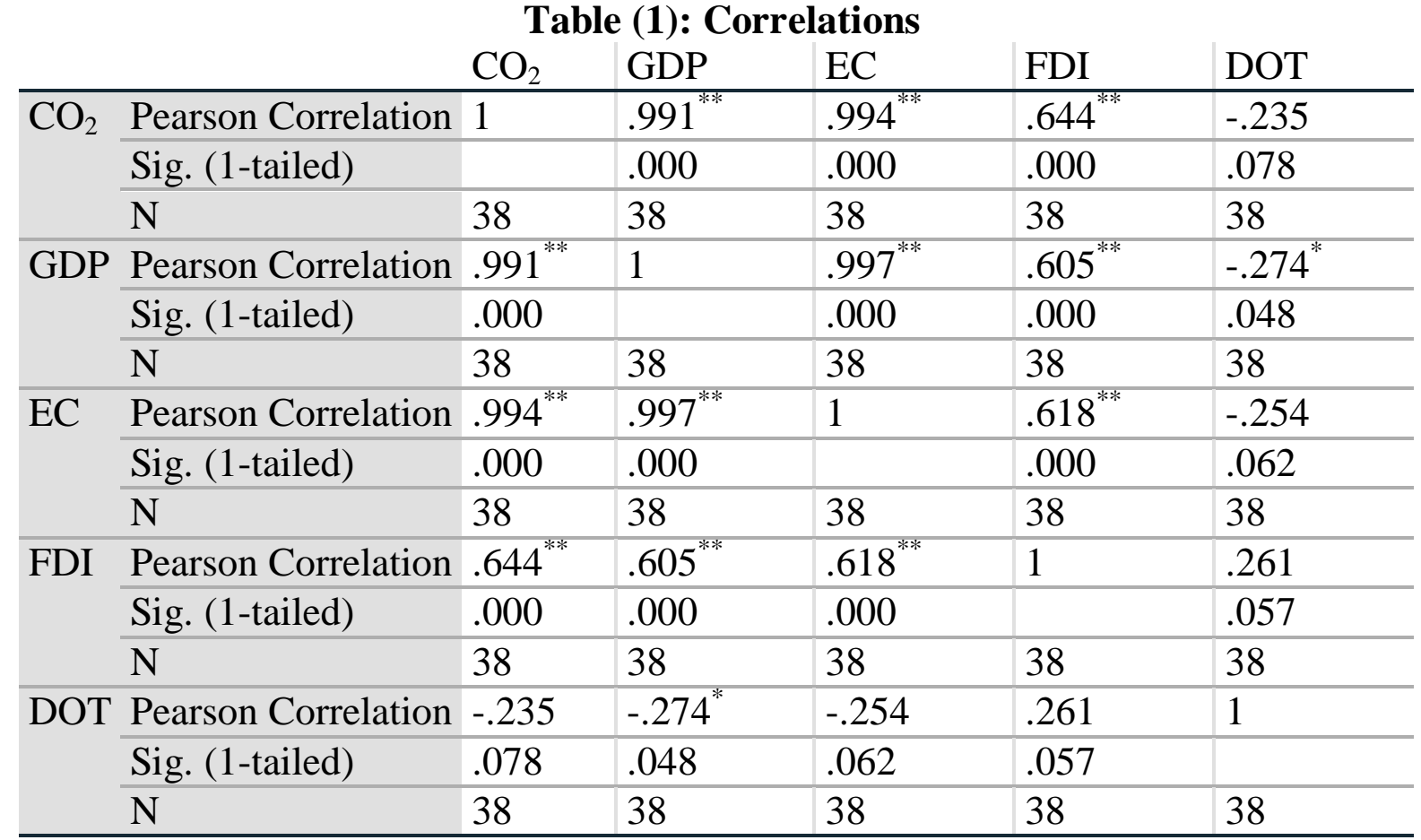

**. Correlation is significant at the 0.01 level (1-tailed).

*. Correlation is significant at the 0.05 level (1-tailed).

From Table (1) it was found that the coefficient of correlation between $\mathrm{CO}_{2}$ and GDP is a positive and strong relationship between them, where the correlation coefficient value is (0.991).Also there is a strong positive relationship between $\mathrm{CO}_{2}$ and $\mathrm{EC}$ (correlation coefficient value is 0.994). There is a positive relationship between $\mathrm{CO}_{2}$ and $\mathrm{FDI}$ (correlation coefficient value is0.644), and a weak negative relationship between $\mathrm{CO}_{2}$ and DOT(correlation coefficient value is-0.235)

\section{To Test the Stationary of Variables}

One of the most common tests to detect threaded silence is the Dickey-Fuller (ADF), the null hypothesis stated that the series had a unit root and it was nonstationary. 
Table (1) to Table (5)displays the unit root tests for the variables at their levels and their first difference. the results indicated that variables were non stationary at levels and they were integrated of order one at the $1 \%, 5 \%, 10 \%$ significance level.

Table (2) results of the unit root tests for variable $\mathrm{CO}_{2}$

to test the Null hypothesis $\quad \mathrm{H}_{0}$ : co2 has a unit root

the Alternative hypothesis $\mathrm{H}_{1}$ : co2 has not a unit root

Table (2) : Augmented Dickey -Fuller test Statistic

\begin{tabular}{|c|c|l|c|c|}
\hline & Level & & ${ }^{\text {st }}$ Difference & \\
\hline Co2 & t-statistic & prob & t-statistic & prob \\
\hline Intercept & -0.150669 & .9361 & $6.341391 * * *$ & 0.00000 \\
\hline ntercept and Trend & -1.983620 & 0.5908 & $6.225631 * * *$ & 0.0000 \\
\hline InCo2 & t-statistic & prob & t-statistic & prob \\
\hline Intercept & -1.652605 & .4463 & -2.319174 & 0.4138 \\
\hline ntercept and Trend & $7.310004 * * *$ & 0.0000 & $7.728935 * * *$ & 0.0000 \\
\hline
\end{tabular}

$* * *$ significant at $1 \%, 5 \%, \& 10 \%$

Table (3) results of the unit root tests for variable EC

to test the Null hypothesis $\quad \mathrm{H}_{0}$ : EC has a unit root

the Alternative hypothesis $\mathrm{H}_{1}$ : EC has not a unit root

Table (3) :Augmented Dickey -Fuller test Statistic

\begin{tabular}{|c|c|c|c|c|}
\hline & Level & & $1^{\text {st }}$ Difference & \\
\hline EC & t-statistic & prob & t-statistic & prob \\
\hline Intercept & 1.404024 & 0.9987 & $-4.665719 * * *$ & 0.0006 \\
\hline Intercept and Trend & -1.289659 & 0.8746 & $-4.791185 * * *$ & 0.0024 \\
\hline Ln EC & t-statistic & prob & t-statistic & prob \\
\hline Intercept & -2.189121 & 0.2134 & $-5.388035 * * *$ & 0.0001 \\
\hline Intercept and Trend & -2.534437 & 0.3108 & $-5.934685 * * *$ & 0.0001 \\
\hline
\end{tabular}

$* * *$ significant at $1 \%, 5 \%, \& 10 \%$

Table (4) results of the unit root tests for variable GDP

to test the Null hypothesis $\quad \mathrm{H}_{0}$ : GDP has a unit root

the Alternative hypothesis $\mathrm{H}_{1}$ : GDP has not a unit root

Table (4): Augmented Dickey -Fuller test Statistic

\begin{tabular}{|c|c|l|c|c|}
\hline & Level & & ${ }^{\text {st }}$ Difference & \\
\hline GDP & t-statistic & prob & t-statistic & prob \\
\hline Intercept & 3.153473 & .00000 & -2.531294 & 0.1167 \\
\hline ntercept and Trend & -1.175781 & 0.9005 & $3.991747 * * *$ & 0.0189 \\
\hline Ln GDP & t-statistic & prob & t-statistic & prob \\
\hline Intercept & -1.996720 & 0.2869 & $3.978961 * * *$ & 0.0040 \\
\hline ntercept and Trend & $4.046414 * * *$ & 0.0161 & $4.465437 * * *$ & 0.0056 \\
\hline
\end{tabular}

*** significant at $1 \%, 5 \%, \& 10 \%$

Table (5) results of the unit root tests for variable DOT

to test the Null hypothesis $\quad \mathrm{H}_{0}$ : DOT has a unit root

the Alternative hypothesis $\mathrm{H}_{1}$ : DOT has not a unit root 
Table (5): Augmented Dickey -Fuller test Statistic

\begin{tabular}{|c|c|c|c|c|}
\hline & Level & & $1^{\text {st }}$ Difference & \\
\hline DOT & t-statistic & prob & t-statistic & prob \\
\hline Intercept & 4.2076 & 0.0023 & $-4.843583 * * *$ & 0.0005 \\
\hline ntercept and Trend & -4.202353 & 0.0113 & -4.676373 & 0.0039 \\
\hline Ln DOT & t-sta & prob & & prob \\
\hline & -4.143844 & 0.0027 & $-4.372772 * * *$ & 0.0014 \\
\hline ntercept and Trend & -4.189867 & 0.0116 & $-4.345477 * * *$ & 0.0076 \\
\hline
\end{tabular}

$* * *$ significant at $1 \%, 5 \%, \& 10 \%$

Table (6) results of the unit root tests for variable FDI

to test the Null hypothesis $\quad \mathrm{H}_{0}$ : FDI has a unit root

the Alternative hypothesis $\mathrm{H}_{1}$ : FDI has not a unit root

Table (6): Augmented Dickey -Fuller test Statistic

\begin{tabular}{|c|c|c|c|c|}
\hline & Level & & $1^{\text {st }}$ Difference & \\
\hline FDI & t-statistic & prob & t-statistic & prob \\
\hline Intercept & -1.84759 & 0.3526 & $-5.049434 * * *$ & 0.0002 \\
\hline Intercept and Trend & -3.514567 & 0.0533 & $-4.975232 * * *$ & 0.0015 \\
\hline Ln FDI & t-statistic & prob & t-statistic & prob \\
\hline Intercept & -1.532168 & 0.5055 & -2.202116 & 0.2092 \\
\hline Intercept and Trend & -2.193540 & 0.4778 & $-5.150394 * * *$ & 0.0010 \\
\hline
\end{tabular}

$* * *$ significant at $1 \%, 5 \%, \& 10 \%$

\section{Granger Causality test}

Table (7) shows the results of causation between the variables in the study where it indicates a binary causal relationship.There is a one-way causal relationship between LNco2 2 and of each of the following variables lnGDP , lnFDI, and lnEC, and there is no causal relation between $\mathrm{Co} 2$ and DTO.

Table (7) : Granger Causality Tests

\begin{tabular}{|c|c|c|c|}
\hline Null Hypothesis: & Obs & F-statis tic & Prob. \\
\hline $\begin{array}{l}\text { LNDTO does not Granger Cause LNCO2 } \\
\text { LNCO2 does not Granger cause LNDTO }\end{array}$ & 36 & $\begin{array}{l}1.58020 \\
0.79121\end{array}$ & $\begin{array}{l}0.2221 \\
0.4622\end{array}$ \\
\hline $\begin{array}{l}\text { LNGDP does not Granger Cause LNCO2 } \\
\text { LNCO2 does not Granger cause LNGDP }\end{array}$ & 36 & $\begin{array}{l}2.49625 \\
5.20230\end{array}$ & $\begin{array}{l}0.0988 \\
0.0113\end{array}$ \\
\hline $\begin{array}{l}\text { LNEC does not Granger Cause LNCO2 } \\
\text { LNCO2 does not Granger Cause LNEC }\end{array}$ & 36 & $\begin{array}{l}0.11868 \\
4.86560\end{array}$ & $\begin{array}{l}0.8885 \\
0.0145\end{array}$ \\
\hline $\begin{array}{l}\text { LN_FDI does not Granger Cause LNCO2 } \\
\text { LNCO2 does not Granger Cause LN_FDI }\end{array}$ & 36 & $\begin{array}{l}3.54881 \\
4.79505\end{array}$ & $\begin{array}{l}0.0409 \\
0.0153\end{array}$ \\
\hline $\begin{array}{l}\text { LNGDP does not Granger Cause LNDTO } \\
\text { LNDTO does not Granger cause LNGDP }\end{array}$ & 36 & $\begin{array}{l}0.84375 \\
3.65849\end{array}$ & $\begin{array}{l}0.4397 \\
0.0375\end{array}$ \\
\hline $\begin{array}{l}\text { LNEC does not Granger Cause LNDTO } \\
\text { LNDTO does not Granger cause LNEC }\end{array}$ & 36 & $\begin{array}{l}1.58233 \\
0.28220\end{array}$ & $\begin{array}{l}0.2216 \\
0.7560\end{array}$ \\
\hline $\begin{array}{l}\text { LN_FDI does not Granger Cause LNDTO } \\
\text { LNDTO does not Granger cause LN_FDI }\end{array}$ & 36 & $\begin{array}{l}0.36164 \\
122415\end{array}$ & $\begin{array}{l}0.6994 \\
0.0001\end{array}$ \\
\hline $\begin{array}{l}\text { LNEC does not Granger Cause LNGDP } \\
\text { LNGDP does not Granger Cause LNEC }\end{array}$ & 36 & $\begin{array}{l}1.72265 \\
5.94207\end{array}$ & $\begin{array}{l}0.1952 \\
0.0065\end{array}$ \\
\hline $\begin{array}{l}\text { LN_FDI does not Granger Cause LNGDP } \\
\text { LNGDP does not Granger Cause LN_FDI }\end{array}$ & 36 & $\begin{array}{l}2.17145 \\
8.91289\end{array}$ & $\begin{array}{l}0.1310 \\
0.0009\end{array}$ \\
\hline $\begin{array}{l}\text { LN_FDI does not Granger Cause LNEC } \\
\text { LNEC does not Granger Cause LN_FDI }\end{array}$ & 36 & $\begin{array}{l}4.34352 \\
5.30383\end{array}$ & $\begin{array}{l}0.0217 \\
0.0104\end{array}$ \\
\hline
\end{tabular}

\section{- Analysis of Common Integration}

The following table ( table 8 ) shows the results of the Johansen test for the common integration of the variables under consideration To determine the 
number of integration vectors, the Trace test, which is based on the null hypothesis, is used to

$\mathrm{H}_{0}$ : the number of integration vectors is less than or equal to $\mathrm{r}$.

$\mathrm{H}_{1}$ : the number of vectors of co-integration equal to $\mathrm{r}+1$

Also, using the Maximum Eigenvalues test, which is based on a zero-force test, $\mathrm{H}_{0}$ : the number of co-integrated products is equal to $\mathrm{r}$.

$\mathrm{H}_{1}$ : the number of vectors of co-integration equal to $\mathrm{r}+1$

Table ( 8 ): Johansen test for the common integration

\begin{tabular}{|c|l|c|l|c|l|}
\hline $\begin{array}{c}\text { Hypothesized } \\
\text { No, of CE }(\mathrm{s})\end{array}$ & Eigenvalue & $\begin{array}{c}\text { Trace } \\
\text { Statistic }\end{array}$ & Prob.** & $\begin{array}{c}\text { Max-eigen } \\
\text { Statistic }\end{array}$ & Prob.** \\
\hline $\mathrm{r}=0$ & 0.801146 & 117.0555 & 0.0000 & 58.14661 & 0.0000 \\
\hline $\mathrm{r} \leq 1$ & 0.497621 & 58.90893 & 0.0033 & 24.78242 & 0.1096 \\
\hline $\mathrm{r} \leq 2$ & 0.361841 & 34.12652 & 0.0149 & 16.17004 & 0.2151 \\
\hline $\mathrm{r} \leq 3$ & 0.245388 & 17.95648 & 0.0209 & 10.13587 & 0.2032 \\
\hline $\mathrm{r} \leq 4$ & 0.195262 & 1.820606 & 0.0052 & 7.820606 & 0.0052 \\
\hline
\end{tabular}

The results shown in the previous table indicate the possibility of acceptance of null hypothesis by the absence of joint integration at $5 \%$ significant level

The results of the above table indicate a long-term equilibrium relationship between per capita carbon emissions and foreign investment, energy consumption, income and trade openness

The study concluded that there is one common integration relationship at a significant level (5\%). This confirms the existence of a long-term equilibrium relationship between the variables of the study After determining the stability of the time series of the variables in that study, and to determine the direction of the causal relationship between these variables,

Causal relationships can be realized in the second temporal slowdown.

The null hypothesis takes the following form:

$\mathrm{H}_{0}: \mathrm{B}=0$ " $\mathrm{X}$ does not Granger Cause $\mathrm{Y}$

The null hypothesis, which indicates that there is no causal relationship in the case of "prob" value is greater than 0.05 
Table (9): The Long-Run Dynamics results.

Dependent Variable: LNCO2

Method: Least Squares (Gauss $-\mathrm{N}$ ew ton / Marquardt steps)

Date: 02/02/19 Time: 00:44

Sam ple: 19772014

Included obs ervations: 38

$\mathrm{LNCO} 2=\mathrm{C}(1)+\mathrm{C}(2)^{\star} \mathrm{LNDTO}+\mathrm{C}(3)^{\star} \mathrm{LN} \_\mathrm{FDI}+\mathrm{C}(4)^{\star} \mathrm{LNEC}+\mathrm{C}(5)^{\star} \mathrm{LNGDP}$

\begin{tabular}{crlrr}
\hline \hline & Coeffic ient & Std. Error & t-Statistic & Prob. \\
\hline \hline C(1) & 5.540396 & 0.949444 & 5.835411 & 0.0000 \\
C(2) & -0.029504 & 0.043402 & -0.679780 & 0.5014 \\
C(3) & -0.231269 & 0.078882 & -2.931821 & 0.0061 \\
C(5) & 0.904381 & 0.233138 & 3.879160 & 0.0005 \\
& 0.099721 & 0.240393 & 0.414825 & 0.6810 \\
\hline \hline R-squared & 0.992552 & Mean dependent var & 11.52768 \\
Adjus ted R-squared & 0.991649 & S.D. dependent var & 0.536263 \\
S.E. of regres sion & 0.049006 & Akaike info criterion & -3.071649 \\
Sum squared resid & 0.079254 & Schwarz criterion & -2.856177 \\
Log likelihood & 63.36133 & Hannan-Quinn criter. & -2.994985 \\
F-s tatis tic & 1099.367 & Durbin-Watson stat & 1.473493 \\
Prob(F-statis tic) & 0.000000 & & & \\
\hline \hline
\end{tabular}

It is noted that a $1 \%$ rise in energy consumption will increase $\mathrm{CO} 2$ emissions by $0.9 \%$.

It is noted that the long-run income elasticity for $\mathrm{CO}_{2}$ emissions is less than the long-run elasticity for $\mathrm{CO}_{2}$ emissions. The long-run effect of DTO is negative but insignificant. The sign of coefficient of FDI term is negative and significant at $1 \%$ level of significance. The long-run effect of GDP is positive but insignificant. The independent variables represent $99 \%$ the change of $\mathrm{CO}_{2}$ Based on the above, the equation of co-integration, which represents the relationship between the variables take the form next one:

$\mathrm{LnCO}_{2}=5.540396-0.029504 \operatorname{lnDTO}-0.2312691 n \mathrm{lnDI}+0.904381 \operatorname{lnEC}$ $+0.099721 \ln$ GDP

-From the estimated equation we find that:

1 - There are significant independent variables ( FDI, EC ) according to the results of the operation of the program E-views 7 in addition to the significance of the amount of constant c

2 - The estimated statistical results of the previous equation agree with the hypothesis of the theory and the economic theory

\section{6-Conclusion and Policy Implications}

This paper investigates the relationship between economic growth and environmental pollution in Egypt based on the EKC hypothesis has been tested by applying ARDL model. The results suggest that there exists a long-run relation among energy consumption, economic growth, trade openness, foreign direct investment and $\mathrm{Co}_{2}$ emissions in Egypt over the period of 1977-2014. The strategic vision of the environment in Egypt by 2030 aims to integrate the environmental dimension in all development and economic sectors in a manner that achieves the security of natural resources and supports the equitable use, 
optimal utilization and investment in it. The government seeks to meet the challenges of climate change, continuous environmental degradation, high emissions and its negative impact on development, thus contributing to balance between the environmental dimension, the economic dimension and the social dimension in order to achieve sustainable development. The most important features of the government plan to protect the environment in the following,

- Developing an integrated system for cleaning and waste management

- Improve water quality, air quality and protection of coastal and marine areas,

- Take action to combat crisis and natural disasters

- Preserving natural resources from land, natural reserves and biological diversity

- Increasing environmental awareness and the culture of dealing with the environment among different groups of society

Future Research: Technological progress and the future of kuznets curve's, Nonlinear Cointegration Analysis and the Environmental Kuznets Curve, Revisiting the Environmental Kuznets Curve and the Role of Energy Consumption

\section{References}

[1] Ahmed, K.,\& Long, W.(2012) "Environmental Kuznets curve and Pakistan: an empirical analysis" Procedia Economics and Finance, 1, 4-13.

[2] Ahmad, N. et al. (2017). "Modelling the $\mathrm{CO}_{2}$ emissions and economic growth in Croatia: Is there any environmental Kuznets curve?". Energy, 123, 164-172

[3] Aghion p. \& Howitt p.(1992) " a Model of Growth through Creative Destruction " Econometrica, vol. 60, no. 2 (march, 1992), 323-351

[4] Aliyu, M. A.(2005) "Foreign Direct Investment and The Environment: Pollution Haven Hypothesis Revisited",Paper presented at:The Eight Annual Conference on Global Economic Analysis, Lubeck Germany,9 -11

[5] Andreonia, J.\& Levinsonb, A.,(2001)" The Simple Analytics of the Environmental Kuznets Curve" Journal of Public Economics 80 , 269-286

[6] Antweiler. W.. Copeland, B. and Taylor. S. (2001). Is FreeTrade Good for the Environment?", American Economic Review,Vol. 91. No. 4.

[7] Apergis \&Payne (2010)"Renewable energy consumption and economic growth: Evidence from a panel of OECD countries" Energy Policy, vol. 38, issue 1, 656-660

[8] Asante. K(2016) " A Study on the Evidence of the Environmental Kuznets Curve Hypothesis in Ghana" the faculty of KAIST in partial fulfilment of the requirements for the KOICA-KAIST Scholarship Program.

[9] BenJebli et al (2016)."Testing environmental Kuznets curve Hypothesis: The Role of Renewable and Non-Renewable Energy Consumption and Trade in OECD Countries". Ecological Indicators, 60, 824-831.

[10] Chow.G.C (2014) "Environmental Kuznets Curve: Conclusive Econometric Evidence for CO2" Pacific Economic Review, 19: 1 .pp. 1-7

[11] De Mello,(1997) "Foreign Direct Investment in Developing Countries and Growth: a Selective Survey", The Journal of Development Studies, Vol. 34, No.1, P. 8.

[12] Dinda, S. (2004)," Environmental Kuznets Curve Hypothesis: A Survey", Ecological Economics, 49, 431-455. 
[13] Elliott, G., Rothenberg, T.J. and Stock, J.H. (1996)," Efficient Tests for an Autoregressive Unit Root", Econometrica, 64, 813-836.

[14] Engle, R. F. and Granger, C. W. J. (1987)," Co-integration and Error Correction: Representation, Estimation, and Testing", Econometrica, 55, 2512

[15] Farhani, O. (2015) “Causal Relationship between $\mathbf{C O}_{2}$ Emissions 'Real GDP' Energy Consumption' Financial Development' Trade Openness and Urbanization in Tunisia”. The Journal of Environment Science Pollution Research, 22:15663-15676.

[16] Frankle, J. \& Rose A.,(2003) "Is Trade Good or Bad for the Environment? Sorting out the Causality" NBER,Working Paper No. 9201.

[17] Grossman, G. M., \& Krueger, A. B. (1991)." Environmental impacts of a North American free trade agreement" (No. w3914). National Bureau of Economic Research.

[18] Grossman, G. M., \& Krueger, A. B, (1995)"Economic Growth and the Environment", The Quarterly Journal of Economics, Vol.110, No.2,May,353-377.

[19] Johansen, S. (1991), "Estimation and Hypothesis Testing of Cointegration Vectors in GaussianVector Autoregressive Models", Econometrica, 59, $1551-1580$

[20] Josic et al (2016) "Testing the environmental Kuznets curve in the case of Croatia"Journal for sustainable development number 2

[21] Justin Tevie, Kristine M. Grimsrud and Robert P. Berrens(2011) Testing the Environmental Kuznets Curve Hypothesis for Biodiversity Risk in the US: A Spatial Econometric Approach" sustainability, ISSN 2071-1050

[22] Kuznets, S. (1955)," Economic Growth and Income Inequality", The American Economic Review, Vol. 45, No.1, pp. 1-28

[23] Ljungwall,Ch \& Rahr, M.L., (2005) "Environmental Policy and the Location of Foreign Direct Investment in China" China: Peking University, China Center for Economic Research .

[24] Mathys ,N. A.,(2002)" In Search of Evidence for the Pollution Haven Hypothesis" Switzerland: University of Lausanne, P. 9.

[25] Mehdi Ben Jebli and Slim Ben Youssef(2015)"The Environmental Kuznets Curve, Economic Growth, Renewable and Non-Renewable Energy, and Trade in Tunisia" MPRA Paper No. 61282.

[26] Michael,G. \& Krueger,A. (1995) "Economic Growth and the Environment", Quarterly Journal of Economics, Vol. 110.

[27] Monserrate et al(2016)"Testing the Environmental Kuznets Curve Hypothesis in Iceland: 1960-2010"Revista de Economía del Rosario. Vol. 19. No. 1.p 5-28.

[28] Nordstrom \& S. Vaughan,( 1999) "Trade and Environment: Special Studies", the world trade organization.

[29] Och.M(2017)" Empirical Investigation of the Environmental Kuznets Curve Hypothesis for Nitrous Oxide Emissions for Mongolia" International Journal of Energy Economics and Policy, 7(1), 117-128.

[30] Porter M.(2008)“Porter's Model of Generic Competitive Strategies" Business Economics, July, Volume 43, Issue 3, pp 55-64

[31] Özokcu, S., \& Özdemir, Ö. (2017)." Economic growth, Energy, and Environmental Kuznets Curve". Renewable and Sustainable Energy Reviews, 72, 639-647. 
[32] Qureshi.M.(2005), 'The Trade-Environment Composition Effect: Evidence From Pakistan". Paper Presented at WIDER and JICA Project Meeting on The Impact of Globalization on the Poor In Asia, 25- 26 April, Tokyo.

[33] Rebelo, Sergio T. (1991): "Long-Run Policy Analysis and Long-Run Growth," Journal of Political Economy, 99(3), 500-52

[34] Robert E. Lucas, (1988) "On the Mechanisms of Economic Development", Journal of monetary economics, vol. 22, no. 1, pp. 3-42.

[35] Rostow w.(1959)" the stages of economic growth " the economic history review, second series, vol. xii, no. i

[36] 34 Scotchmer S. and. Menell .P (2005) " Intellectual Property" UC Berkeley Public Law Research Paper No. 741724

[37] Saboori, B., Sulaiman, J., \& Mohd, S. (2012)."Economic Growth and $\mathbf{C O}_{2}$ Emissions in Malaysia: a Cointegration Analysis of the Environmental Kuznets Curve." Energy Policy, 51, 184-191.

[38] Sergio T. Rebelo, (June 1991), «Long-run Policy Analysis and Long-Run Growth,» Journal of Political Economy, vol. 99, no. 3 , pp. 500-521.

[39] Shahbaz, M., Khraief, N., Uddin, G. S., \& Ozturk, I. (2014). "Environmental Kuznets Curve in an open Economy: A Bounds Testing and Causality Analysis for Tunisia". Renewable and Sustainable Energy Reviews, 34,325-336.

[40] Srinivasan, P. (2014)“Causality among Energy Consumption, CO2 Emission, Economic Growth and Trade: A Case of India". The Journal of Academic Research in Economics, 6(3): 315-335

[41] Sunday, O., (2016)"Economic Development and Environmental Degradation: The Environmental Kuznets Curve" Center for Economic Development \& Social Change, September $18^{\text {th }}$

[42] Sunday, O.,(2016) "Environmental Kuznets curve hypothesis in subSaharan African countries: evidence from panel data analysis." International Journal of Environment and Pollution Research Vol.4, No.1, pp.39-51, March

[43] Taguchi. H(2012) "The Environmental Kuznets curve in asia :The case of Sulphur and carbon emissions" , Asia-Pacific Development Journal,vol.19, No.2,December, $\mathrm{p} 80$

[44] Tao SONG a, Tingguo ZHENG b,*, Lianjun TONG(2008) "An Empirical test of the Environmental Kuznets curve in China: A panel cointegration Approach" China Economic Review $19,381-392$

[45] Tevie.J et al (2011) "testing the environmental kuznets curve hypothesis for biodiversity risk in the us: a spatial econometric approach" sustainability 3(11):2182-2199 - december

[46]Tobey J. (1990)" The Effects of Domestic Environmental Policies on Patterns of World Trade: An Empirical Test" EconPapers ,vol. 43, issue 2, 191-209

[47] Umed Temurshoev,(2006) "Pollution Haven Hypothesis or Factor Endowment Hypothesis: Theory and Empirical Examination for U.S and China",Working Paper Series, ISSN 1211 - 3298, CERGE-EI, Prague, March. 